\title{
The Contemporary Tax Journal
}

Volume 2

Issue 1 Spring 2012

Article 10

$5-2012$

\section{Election by Certain Individuals to Have Their Income Tax Return Prepared by the IRS}

Follow this and additional works at: https://scholarworks.sjsu.edu/sjsumstjournal

Part of the Taxation-Federal Commons

\section{Recommended Citation}

(2012) "Election by Certain Individuals to Have Their Income Tax Return Prepared by the IRS," The Contemporary Tax Journal: Vol. 2 : Iss. 1 , Article 10.

https://doi.org/10.31979/2381-3679.2012.020110 https://scholarworks.sjsu.edu/sjsumstjournal/vol2/ iss $1 / 10$

This Focus on Tax Policy is brought to you for free and open access by the Lucas Graduate School of Business at SJSU ScholarWorks. It has been accepted for inclusion in The Contemporary Tax Journal by an authorized editor of SJSU ScholarWorks. For more information, please contact scholarworks@sjsu.edu. 


\title{
Focus on Tax Policy: An Introduction
}

\author{
By: Professor Annette Nellen \\ SJSU MST Program Director
}

This section of The Contemporary Tax Journal includes tax policy work of SJSU MST students. We offer it here and on the journal website to showcase the range of tax knowledge students gain from the program and to provide a public service. We think the analysis of existing tax rules and proposals using objective tax policy criteria will be of interest to lawmakers, staff and individuals interested in better understanding taxation.

One of the learning objectives of the SISU MST Program is:

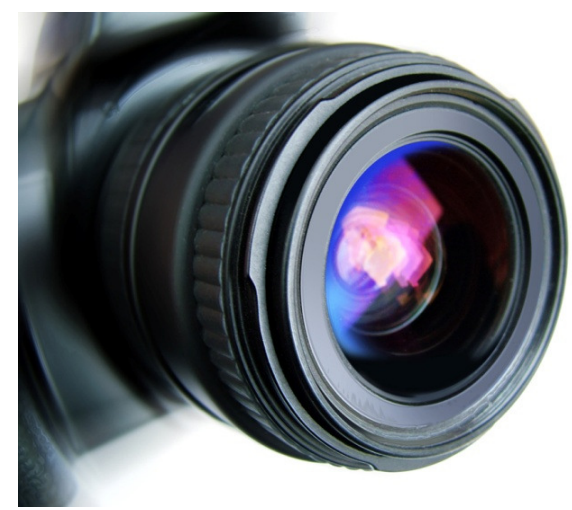

To develop an appreciation for tax policy issues that underpin our tax laws.

Students learn about principles of good tax policy starting in their first MST class - Tax Research and Decision-making. The AICPA's tax policy tool, issued in 2001, ${ }^{56}$ which lays out ten principles of good tax policy, is used to analyze existing tax rules as well as proposals for change.

Beyond their initial tax course, SJSU MST students work on tax policy in the capstone course. In other courses, such as corporate taxation and accounting methods, students learn the policy underlying the rules and concepts of the technical subject matter in order to better understand the rules and to learn more about the structure and design theory of tax systems. The MST Program also has an elective course - Tax Policy and Tax Reform. ${ }^{57}$

Two tax policy analyses are included in this section and join the growing archive of such analyses on the journal website (under "Focus on Tax Policy").

1) Increase in Standard Mileage Rate for Certain Charitable Work (here)

2) Election by Certain Individuals to Have Their Income Tax Return Prepared by the IRS (next page)

\footnotetext{
${ }^{56}$ AICPA, Tax Policy Concept Statement 1 - Guiding Principles of Good Tax Policy: A Framework for Evaluating Tax Proposals, 2001; available at http://www.aicpa.org/INTERESTAREAS/TAX/RESOURCES/TAXLEGISLATIONPOLICY/Pages/TaxReform.aspX. Professor Nellen was the lead author of this AICPA document.

${ }^{57}$ Information on this MST course (BUS 225R) can be found at http://www.cob.sjsu.edu/nellen a/bus225R reading.html.
} 


\title{
Election by Certain Individuals to Have Their Income Tax Return Prepared by the IRS
}

\author{
By: MST Students in Fall 2011, BUS 223A Tax Research Class, Fall 2011
}

H.R. 1069 (112th Congress) proposes to amend IRC Section 6020, Returns prepared for or executed by Secretary, to allow certain unmarried individuals who claim the standard deduction (rather than itemizing deductions) to have their income tax return prepared by the IRS. Individuals using the surviving spouse or head-of-household filing status would not be eligible to make the election. Also, individuals with gross income from a trade or business may not make the election.

An individual making the election can still opt not to have the IRS-prepared return filed. Per H.R. 1069 , the IRS "may not use either the election or failure to sign in any way that disadvantages the taxpayer."

The IRS must report to Congress by August 31, 2013, how many returns were prepared under the new rule, whether the program should be expanded to include other taxpayers, and whether any changes are needed.

The sponsor of H.R. 1069, Congressman Jim Cooper (D-TN), states that the purpose of the proposal is to simplify compliance for individuals and utilize information the IRS already has. Per the sponsor: "Make the IRS do your paperwork. They already have much of your tax information like copies of your W-2 and 1099s. Today they use that information to catch you if you make a mistake. Why not get the IRS to use that information to help you instead of punish you?"60

The policy analysis below uses the ten principles of good tax policy outlined in the AICPA Statement \#1, Guiding Principles of Good Tax Policy: A Framework for Evaluating Tax Poposals, to analyze H.R. 1069.

\section{Principles of Good Tax Policy Evaluation}

\begin{tabular}{|c|l|c|}
\hline Principle & \multicolumn{1}{c|}{ Application } & $+/-$ \\
\hline $\begin{array}{c}\text { Equity and Fairness } \\
\text { Similarly situated } \\
\text { taxpayers treated } \\
\text { similarly. }\end{array}$ & $\begin{array}{l}\text { Within the narrowly defined category of eligible taxpayers }- \text { single } \\
\text { (other than those using either the head-of-household or surviving } \\
\text { spouse filing status), claiming the standard deduction and without } \\
\text { gross income from a trade or business, taxpayers are treated the } \\
\text { same, regardless of income level. However, not all individual } \\
\text { taxpayers with similar income levels are treated similarly. For } \\
\text { example, an individual with } \$ 50,000 \text { of wage income may take }\end{array}$ & $+/-$ \\
\hline
\end{tabular}

${ }^{60}$ Congressman Cooper press release of March 15, 2011; available at http://cooper.house.gov/index.php?option=com content\&task=view\&id=456\&ltemid=73. 


\begin{tabular}{|c|c|c|}
\hline & $\begin{array}{l}\text { advantage of the election to have the IRS prepare her return, but an } \\
\text { individual with the same income who claims the head-of-household } \\
\text { filing status, may not make the election. Some of the inequity can be } \\
\text { excused though because H.R. } 1069 \text { is a trial measure as indicated by } \\
\text { the fact that it is a new program and the IRS must report on its } \\
\text { effectiveness after one year and the feasibility of extending the } \\
\text { program to other taxpayers. }\end{array}$ & \\
\hline $\begin{array}{l}\text { Certainty } \\
\text { The tax rules should } \\
\text { clearly specify when } \\
\text { the tax is to be paid, } \\
\text { how it is to be paid, } \\
\text { and how the amount } \\
\text { to be paid is to be } \\
\text { determined. }\end{array}$ & $\begin{array}{l}\text { H.R. } 1069 \text { does not include the details of how and when the election } \\
\text { is to be made, how to ensure that a return is filed and how individuals } \\
\text { submit information, such as eligibility for certain credits and special } \\
\text { reporting requirements. For example, a spouse in a same-sex } \\
\text { marriage in a community property state is required to report one-half } \\
\text { of each spouse's community property income and withholding on a } \\
\text { return and is not allowed to file as married for federal income tax } \\
\text { purposes. Guidance would be needed as to how the information } \\
\text { needed by the IRS to prepare the returns would be submitted. } \\
\text { Guidance will also be needed on how the IRS obtains information } \\
\text { from electing individuals on their sales of capital assets. } \\
\text { The IRS will also have to provide guidance on what income from a } \\
\text { trade or business means. Does that include a sole proprietorship, a } \\
\text { farm, an interest in a partnership or S corporation, a rental property, } \\
\text { or any income for which a W-2 or } 1099 \text { is not issued? }\end{array}$ & - \\
\hline $\begin{array}{l}\text { Convenience of } \\
\text { Payment } \\
\text { A tax should be due } \\
\text { at a time or in a } \\
\text { manner that is most } \\
\text { likely to be } \\
\text { convenient for the } \\
\text { taxpayer. }\end{array}$ & $\begin{array}{l}\text { Presumably, individuals would pay their tax in the same manner as } \\
\text { without H.R. 1069. If the IRS handles the filing for an individual, but } \\
\text { does not also handle calculation of estimated tax payments (if any) } \\
\text { for the subsequent tax year, individuals may have large liabilities and } \\
\text { penalties when they file the subsequent year's return. } \\
\text { H.R. } 1069 \text { allows participating individuals the choice of filing the IRS } \\
\text { prepared return or preparing their own. Depending on how long it } \\
\text { takes for the IRS to provide the return to electing taxpayers, such } \\
\text { taxpayers may not have enough time to prepare their own return } \\
\text { should they decide to do so after seeing the IRS return. While they } \\
\text { can file an extension of time to file, they may need more time to } \\
\text { determine how much (if any) they owe to the IRS or may face burdens } \\
\text { in getting an extension filed. }\end{array}$ & +1 \\
\hline
\end{tabular}




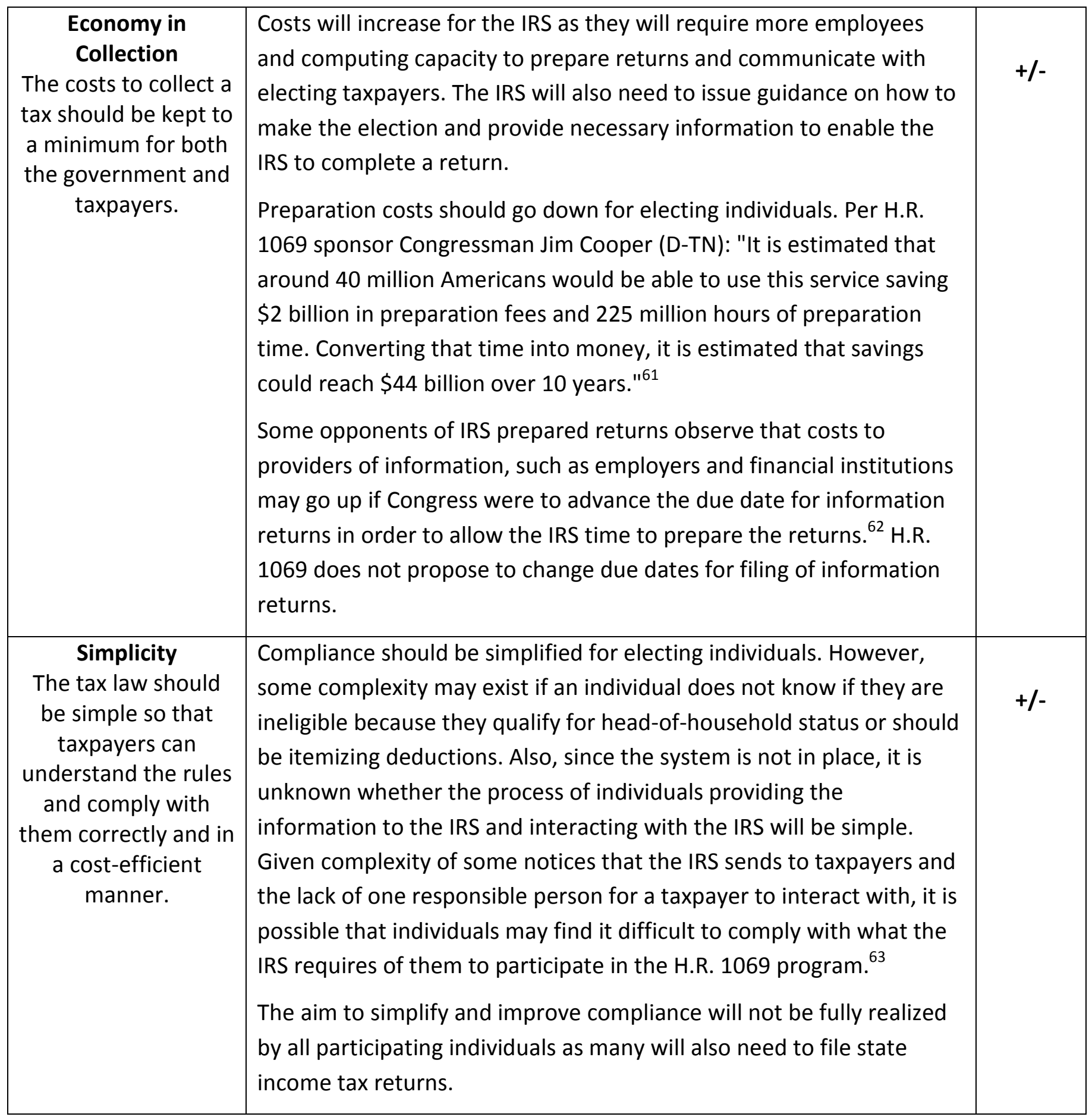

${ }^{61}$ Congressman Cooper press release of March 15, 2011; available at http://cooper.house.gov/index.php?option=com content\&task=view\&id=456\&ltemid=73.

${ }^{62}$ See letter provided to the Senate Finance Committee by Joseph Cordes, Professor of Economics at The George Washington University and Arlene Holen, Senior Fellow at the Technology Policy Institute, 4/25/11; available at http://www.techpolicyinstitute.org/files/comment\%20to\%20senate\%20finance1.pdf.

${ }^{63}$ For example, in the 2011 National Taxpayer Advocate report to Congress, it is noted that about $78 \%$ of examinations are conducted by correspondence. The report notes that such examinations occur "in a highly automated campus setting where no single IRS employee was responsible for the audit, making it more difficult for the taxpayer to communicate with the IRS about his or her case." IR-2012-6 (1/11/12); http://www.irs.gov/newsroom/article/0,id=252284,00.html. 


\begin{tabular}{|c|c|c|}
\hline $\begin{array}{c}\text { Neutrality } \\
\text { The effect of the tax } \\
\text { law on a taxpayer's } \\
\text { decisions as to how } \\
\text { to carry out a } \\
\text { particular } \\
\text { transaction or } \\
\text { whether to engage in } \\
\text { a transaction should } \\
\text { be kept to a } \\
\text { minimum. }\end{array}$ & $\begin{array}{l}\text { To be effective, H.R. } 1069 \text { must change taxpayer behavior to } \\
\text { encourage eligible individuals to have the IRS prepare their return, } \\
\text { rather than preparing them on their own, purchasing tax preparation } \\
\text { software, using a VITA site, }{ }^{64} \text { or hiring a paid return preparer. }\end{array}$ & - \\
\hline $\begin{array}{l}\text { Economic Growth } \\
\text { and Efficiency } \\
\text { The tax system } \\
\text { should not impede } \\
\text { or reduce the } \\
\text { productive capacity } \\
\text { of the economy. }\end{array}$ & $\begin{array}{l}\text { The H.R. } 1069 \text { tax preparation proposal will result in some loss of } \\
\text { revenue for return preparers as well as for companies selling tax } \\
\text { preparation software. Given the small subset of eligible taxpayers and } \\
\text { the reality that not all will take advantage of the IRS preparation } \\
\text { services, the effect is likely to be low. }\end{array}$ & $+/-$ \\
\hline $\begin{array}{c}\text { Transparency and } \\
\text { Visibility } \\
\text { Taxpayers should } \\
\text { know that a tax } \\
\text { exists and how and } \\
\text { when it is imposed } \\
\text { upon them and } \\
\text { others. }\end{array}$ & $\begin{array}{l}\text { The IRS will need to find ways to let individuals know of the new } \\
\text { preparation program and how to participate. Because the IRS no } \\
\text { longer mails tax forms and instructions to taxpayers, it may be } \\
\text { challenging for the IRS to find effective ways to let individuals know of } \\
\text { the program. }\end{array}$ & - \\
\hline $\begin{array}{l}\text { Minimum Tax Gap } \\
\text { A tax should be } \\
\text { structured to } \\
\text { minimize non- } \\
\text { compliance. }\end{array}$ & $\begin{array}{l}\text { H.R. } 1069 \text { should result in a small decrease in the tax gap as it may } \\
\text { improve compliance and better ensure that all of the W-2 and } 1099 \\
\text { forms an individual receives are reporting on the return and that any } \\
\text { deductions or credits are properly computed and claimed. } \\
\text { The program may result in some individuals paying more tax than } \\
\text { they owe (a reverse tax gap effect) because they may not know of } \\
\text { special deductions or credits or filing status they are eligible for unless } \\
\text { the IRS is able to incorporate some type of questionnaire, for } \\
\text { example, that helps individuals determine this information. }\end{array}$ & $+/-$ \\
\hline $\begin{array}{l}\text { Appropriate } \\
\text { Government } \\
\text { Revenues } \\
\text { The tax system } \\
\text { should enable the }\end{array}$ & $\begin{array}{l}\text { The government should be able to estimate the cost of creating a } \\
\text { system whereby the IRS prepares returns for some taxpayer and the } \\
\text { likely tax revenue to be collected. }\end{array}$ & + \\
\hline
\end{tabular}

${ }^{64}$ VITA stands for Volunteer Income Tax Assistance which is a program run by the IRS where trained volunteers prepare tax returns for primarily low-income individuals. See http://www.irs.gov/individuals/article/0, id=107626,00.html. 
government to

determine how

much tax revenue

will likely be

collected and when.

\section{Conclusion}

The aim of H.R. 1069, reducing compliance costs for individuals and reducing the likelihood of missed reporting of W-2s and 1099s, seems laudable. Yet, there are many details to work out, such as creating a system to enable the IRS to notify eligible taxpayers and to prepare the returns timely and accurately.

Possible improvements to better enable H.R. 1069 to meet the principles of good tax policy include:

- Providing funding to the IRS to enable them to comply with the legislative proposal including being able to make eligible individuals aware of the program.

- Piloting the program first in states without an income tax so that the tax compliance burden of electing individuals is reduced. Should the system work, later expansion could be with states that allow a similar program so that individuals are more inclined to elect to use the system because both their federal and state income filing would be simplified.

- Incorporate a system to help individuals and the IRS preparers know if the individuals are eligible for preferential deductions, credits or filing status. Interactive tools similar to what the IRS currentlyuses, for example, to help inctividuals know if they are required to file, could be considered (http://www.irs.gov/ita/).

- Reduce the likelihood of individuals not knowing what W-2s and 1099s were issued to them but not received by having the IRS provide that information to them prior to filing with enough time for individuals to file. Such a system was proposed by IRS Commissioner Shulman in April 2011. ${ }^{65}$

- Simplify the individual income tax system to make it easier for individuals to file their returns on their own or for the IRS to do so without the need to gather numerous pieces of information.

${ }^{65}$ See remarks of Commissioner Shulman at the National Press Club, IR-2011-38 (4/6/11); available at http://www.irs.gov/newsroom/article/0, id=238204,00.html. 